\title{
KEKHASAN CERITA PENDEK JAWA MODERN (CERKAK) ABAD 21: KAJIAN IDEALISME PENGARANG DAN KARAKTERISTIK KARYANYA
}

\author{
Suwarni \\ Universitas Negeri Surabaya \\ Email: suwarni@unesa.ac.id \\ Sri Sulistiani \\ Universitas Negeri Surabaya \\ Email: srisulistiani@unesa.ac.id
}

\begin{abstract}
Abstrak
Cerita pendek berbahasa Jawa merupakan salah satu genre dalam sastra Jawa modern. Cerita pendek (cerpen) dalam sastra Jawa modern disebut dengan istilah cerita cekak (cerkak). Fokus kajian cerpen-cerpen berbahasa Jawa ini adalah cerpen-cerpen yang termuat dalam majalah berbahasa Jawa, seperti majalah Jaya Baya dan majalah Panyebar Semangat. Kedua majalah ini merupakan barometer sastra Jawa yang ada di Jawa Timur. Tulisan ini mengulik tentang bagaimanakah kedudukan wanita dalam cerpen-cerpen berbahasa Jawa pada tahun 2002?; sejauhmana cerpencerpen berbahasa Jawa tahun 2002 mencerminkan peran dan kedudukan wanita seperti yang terdapat dalam dunia nyata?; dan dapatkah cerpencerpen berbahasa Jawa tahun 2002 dipakai sebagai salah satu media dalam upaya meningkatkan kualitas kaum wanita? Tulisan ini berargumen bahwa terdapat peran substantif dan peran prestatif dalam cerpen yaitu peran wanita di luar rumah, misalnya peran wanita dalam perkumpulan, organisasi, dan dunia peran prestatif.
\end{abstract}

Kata Kunci: cerpen, cerkak, sastra Jawa, cerita pendek Jawa modern.

\begin{abstract}
Short story of Java language is one genre in modern Javanese literature. Short story (cerpen) in a modern Javanese literature termed insufficient story (cerkak). The focus of this study of short stories is the Java language short stories contained in the Java-language magazines, such as magazines and periodicals Panyebar Jaya Baya spirit. Both of these magazines is a barometer of Javanese literature in East Java. This paper mengulik about how the position of women in the Java language short stories in 2002 ?;
\end{abstract}


the extent of short stories in 2002 Java language reflects the role and status of women as found in the real world ?; and can speak Javanese short story of 2002 is used as one of the media in an effort to improve the quality of women? This paper argues that there are substantive role and the role of Achievement in the short story is the role of women outside the home, for example, the role of women in associations, organizations, and the role of world prestatif.

Keywords: cerpen, cerkak, Javanese literature, modern Javanese literature.

\section{PENDAHULUAN}

Cerita pendek berbahasa Jawa merupakan salah satu genre dalam sastra Jawa modern. Karya-karya tersebut sebagian besar dimuat dalam majalah berbahasa Jawa, seperti Jaya Baya dan Panyebar Semangat. Kedua majalah berbahasa Jawa itu terbit di Jawa Timur. Suripan Sadi Hutomo (1990:6) menyatakan bahwa kedua majalah itu sangat berpengaruh dan tetap bertahan. Panyebar Semangat terbit pertama kali di Kediri 2 September 1933 dan Jaya Baya terbit pertama 1 Desember 1945. Kedua majalah ini karena usianya yang sangat tua, maka keduanya dapat digunakan sebagai tolok ukur pertumbuhan dan perkembangan kesusasteraan Jawa modern, baik cerkak maupun guritan.

Cerita pendek (cerpen) dalam sastra Jawa modern disebut dengan istilah cerita cekak (cerkak). Nurgiyantoro (1995: 9) menyatakan bahwa cerita pendek merupakan bentuk fiksi yang berkedudukan sama dengan dengan novel atau roman. Dalam istilah lain, ia sering disebut dengan nama short story. Perbedaan cerita pendek dengan novel adalah (1) cerpen secara formalitas lebih pendek, (2) alur cerita pendek bersifat tunggal, (3) novel dikondisikan memiliki alur bercabang, (4) jumlah pelaku dalam cerita pendek terbatas, (5) latar cerpen tidak perlu detail seperti 
novel, dan (6) adanya unsur unity yang sangat kuat dalam cerita pendek. Dengan demikian cerpen lebih padat, sehingga mudah dipahami dan mudah dibaca, dalam waktu singkat pembaca dapat memahami cerpen secara menyeluruh. Hal ini sangat menguntungkan bagi pembaca dan pencipta cerpen.

Sastra Jawa cerita pendek disebut cerita cekak, dan lebih dikenal dengan nama cerkak. Jenis karya tersebuttelah lama menjadi perhatian para peneliti Sastra Jawa. Mereka menyadari bahwa sastra Jawa memiliki nilai yang berbeda dengan karya sastra yang lain, misalnya karya sastra Indonesia. Sesuai dengan kepribadian masyarakat pendukungnya, Cerkak memiliki nilai estetika, etika, edukasi, dan moral yang tinggi. Nilai-nilai itu oleh pengarang diangkat menjadi tema karyanya.

Jika diamati secara teliti, dunia wanita dapat diterjemahkan dalam cerpen-cerpen berbahasa Jawa, sehingga pembaca, khususnya masyarakat Jawa dapat memahami keberadaan wanita yang tergambar dalam cerita pendek tersebut. Di samping itu, ia dapat mencontoh sikap yang baik dalam karya sastra tersebut. Hal ini sesuai dengan pendapat Heratu (dalam Darni, 1997) yang menyatakan bahwa sastra merupakan sarana efektif untuk menterjemahkan dunia batin wanita.

Melalui penelitian cerpen-cerpen berbahasa Jawa yang termuat dalam majalah berbahasa Jawa seperti majalah Jaya Baya dan majalah Panyebar Semangat, peneliti ingin mengetahui sejauh mana para penulis, baik pria maupun wanita meletakkan peran dan kedudukan wanita dalam perencanaan pembangunan yang berwawasan jender. Di samping itu, ingin diketahui juga tentang peran cerpen-cerpen tersebut dipakai sebgai salah satu media dalam uapaya meningkatkan kualitas peran ganda wanita 
sebagai mitra sejajar pria dalam keluarga dan masyarakat. Hal ini seuat dengan tendensi sastra yang dapat mendidik masyarakat.

Fokus kajian cerpen-cerpen berbahasa Jawa ini adalah cerpen-cerpen yang termuat dalam majalah berbahasa Jawa, seperti majalah Jaya Baya dan majalah Panyebar Semangat. Kedua majalah ini merupakan barometer sastra Jawa yang ada di Jawa Timur. Untuk itu, peneliti mengambil dan menitikberatkan kedua majalah itu dengan masa terbit tahun 2002. Harapan peneliti, keberadaan peran dan kedudukan wanita dalam pembangunan nasional tergambar dalam cerpen-cerpen yang termuat dalam kedua majalah tersebut.

Permasalahan pokok yang akan dipecahkan dalam penelitian ini difokuskan pada peran dan kedudukan wanita dalam cerpen-cerpen berbahasa Jawa pada tahun 2002. Secara rinci rumusan masalah penelitian ini dikemukakan sebagai berikut: (1) Bagaimanakah kedudukan wanita dalam cerpen-cerpen berbahasa Jawa pada tahun 2002? (2) Bagaimanakah peran wanita dalam cerpen-cerpen berbahasa Jawa pada tahun 2002? (3) Sejauhmana cerpen-cerpen berbahasa Jawa tahun 2002 mencerminkan peran dan kedudukan wanita seperti yang terdapat dalam dunia nyata? (4) Bagaimanakah para cerpenis berbahasa Jawa tahun 2002 menempatkan posisi wanita dan pria sebagai manifes dukungan terhadap perencanaan pembangunan yang berwawasan jender? (5) Dapatkah cerpen-cerpen berbahasa Jawa tahun 2002 dipakai sebagai salah satu media dalam upaya meningkatkan kualitas kaum wanita?

Berdasarkan permasalahan tersebut di atas, tujuan penelitian ini ada beberapa butir, antara lain (1) Untuk mendeskripsikan kedudukan wanita dalam cerpen-cerpen berbahasa Jawa tahun 2002; (2) Untuk mendeskripsikan peran wanita dalam cerpen-cerpen berbahasa Jawa 124 | ISSN: 22477-5150 http://journal.unesa.ac.id/index.php/jpi 
tahun 2002; (3) Untuk mengetahui cerpen-cerpen berbahasa Jawa yang mencerminkan peran dan kedudukan wanita seperti dalam dunia nyata; (4) Untuk mendeskripsikan cerpen-cerpen berbahasa Jawa tahun 2002 yang memposisikan wanita dan pria sebagai manifes dukungan perencanaan pembangunan yang berwawasan jender; (5) Untuk mencari cerpen-cerpen berbahasa Jawa tahun 2002 yang memenuhi syarat untuk digunakan sebagai sarana pendidikan meningkatkan kualitas peran wanita.

Penelitian ini diharapkan dapat memberikan kontribusi yang positif terhadap berbagai pihak, antara lain (1) Hasil penelitian ini dapat memberikan sumbangan terhadap perkembangan sastra umumnya dan sastra Jawa khususnya, terutama dalam bidang kritik sastra dan sejarah sastra; (2) Hasil penelitian ini diharapkan berkontribusi terhadap pengarang cerpen yang terdapat dalam majalah Jaya Baya dan Panyebar Semangat tahun 2002 untuk meningkatkan kualitas karya sastranya, khususnya cerpen; (3) Hasil penelitian ini sangat berguna untuk memperdalam cakrawala studi kajian wanita; (4) Hasil penelitian diharap dapat dijadikan pertimbangan dalam mengambil keputusan bagi para pengambil kebijakan di pemerintah daerah, khususnya Pemerintah Kota Surabaya, dan Pemerintah Provinsi Jawa Timur dalam rangka membuat kebijakan yang berkaitan dengan perempuan. Hal ini perlu dikemukakan mengingat catatan BPS menyebutkan tahun 1980, 1985, dan 199persentase wanita bekerja rata-rata mengalami kenaikan 2,92\%, sedangkan yang mencari kerja rata-rata mengalami kenaikan $0,39 \%$, dan angkatan kerja wanita rata-rata mengalami kenaikan 3,6 \%. Data ini akan mengalami perubahan setiap masa. Oleh karena itu perlu adanya kebijakan yang baik bagi wanita agar dapat berperan dalam pembangunan 
nasional.

\section{TINJAUAN PUSTAKA}

Tarigan (1985) menyatakan bahwa ciri khas cerita pendek antara lain: (a) ciri utama cerita pendek adalah brevity, unity, dan intensity (singkat, padu, dan intensif); (b) Unsur utama cerita pendek ialah scene, character, dan action (adegan, tokoh, dan gerak); (c) Bahasa cerita pendek memiliki ciri incisive, sugestive, dan alert (tajam, sugestif, dan menarik); (d) Cerita pendek harus mengandung interpretasi pengarang tentang konsepnya mengenai kehidupan, secara langsung maupun tidak langsung; (e) Cerita pendek harus menimbulkan satu efek dalam pikiranpembaca; (f) Cerita pendek harus menimbulkan perasaan pada pembaca bahwa jalan ceritalah yang pertama-tama menarik perasaan dan kemudian menarik pikiran; (g) Cerita pendek mengandung insiden-insiden yang dipilih dengan sengaja, dan yang bisa menimbulkan pertanyaan-pertanyaan dalam pikiran pembaca; (h) Dalam sebuah cerita pendek sebuah insiden yang terutama yang menguasai cerita; (I) Cerita pendek harus memiliki seorang pelaku yang utama; (j) Cerita pendek memiliki satu efek atau kesan yang menarik; (k) Cerita pendek bergantung pada satu situasi; (I) Cerita pendek memberikan impresi tunggal; (m) Cerita pendek memberikan suatu kebulatan efek; (n) Cerita pendek menyajikan satu emosi; (o) Jumlah katakata yang terdapat dalam cerita pendek biasanya di bawah 100 kata, tidak boleh lebih dari 100 kata.

Kajian cerpen dalam penelitian ini adalah cerpen berbahasa Jawa yang dimuat dalam majalah berbahasa Jawa, terutama majalah Jaya Baya yang diterbitkan oleh Yayasan Djojobojo dan majalah Panyebar Semangat

yang diterbitkan oleh PT Pancaran Semangat Jaya. Keberadaan kedua 126 | ISSN: 22477-5150 http://journal.unesa.ac.id/index.php/jpi 
majalah tersebut sudah cukup tua, yaitu setua usia negara Republik Indonesia, sekitar tahun 1945.

\section{Istilah Cerpen dalam Sastra Jawa Disebut Carita Cekak (Carkak)}

Rene Wellek dan Austin Warren (1974) menyatakan bahwa unsur yang terdapat dalam sastra ada dua macam, yaitu unsur intinsik dan unsur ekstrinsik. Unsur instriksik adalah unsur yang membangun sebuah cerita, misalnya tema, alur cerita, latar belakang, sudut pandang, tokoh, karakter tokoh, gaya bahasa,dan sebgaainya. Sedangkan unsur ekstrinsik ialah unsur yang secara tidaklangsung membentuk sebuah cerita pendek, misalnya unsur agama, politik, wanita, sosial, kebudayaan, kepercayaan, dan sebagainya.

Keberadaan kritik sastra feminis tidak bisa lepas dari feminisme. Dalam bidang sastra, pelecehan wanita dapat dilihat dari tulisan sebagian besar penulis pria yang seolah-olah menganggap bahwa semua pembacanya laki-laki (Djajanegara, 1987). Mereka cenderung meletakkan wanita sebagai makhluk yang lemah. Oleh karena itu, wanita bangkit untuk menciptakan pendekatan yang khas wanita yang tidak terikat oleh pendekatan laki-laki.

Humm (dalam Darni, 1997) menyatakan bahwa ada asumsi tentang kritik feminis, yaitu (1) sastra dan kritik sastra sejak awal telah dimanipulasi oleh gender. (2) Ada hubungan antara seks dengan strategi penulisan. (3) Para kritikus pria sering berbeda haluan, sekalipun ia menyatakan bahwa dalilnya kritik feminis, namun ia juga menggunakan norma-norma pria. Rice (dalam Darni, 1997) menyatakan bahwa kritik sastra feminis memiliki dua kategori, yaitu (1) womwn is reader, artinya wanita hanya sebagai 
konsumen atas karya sastra kaum laki-laki. (2) Woman is writer, artinya kaum wanita sebagai penghasil teks sastra.

Tahap awal analisis cerpen berbahasa Jawa tahun 2002 dilakukan dengan pendekatan struktural, artinya peneliti mencari peran dan kedudukan wanita dengan mengnalisis unsur ekstrinsik cerpen-cerpen berbahasa Jawa tersebut.

Peran wanita dalam cerpen-cerpen berbahasa Jawa tahun 2002 merupakan bagian darikegiatan yang dilakukan oleh wanita seperti yang tercermin dalam bentuk tingkah laku keseharian para tokoh wanita. Sedang kedudukan wanita dalam cerpen-cerpen berbahasa Jawa tahun 2002 adalah sebagai status yang dimiliki para tokoh wanita dalam kaitannya dengan para tokoh lain dalam cerpen. Berkaitan dengan istilah peran dan kedudukan wanita memiliki makna yang hampir sama. Namun peneliti mencoba untuk memilah kedua istilah itu, sehingga tampak jelas bedanya. Dini (1994) menyatakan bahwa peran wanita dalam sastra ada dua macam, yaitu (a) sebagai pekerja dalam penciptaan sastra, dan (2) sebagai tokoh cerita. Peran pertama kurang mendapat perhatian dalam analisis sastra khususnya cerita pendek. Peran kedua lebih tertumpu pada analisis cerita pendek. la merupakan tokoh cerita dalam cerpen.

Hasniah (1994:5) menyatakan bahwa peran dan kedudukan wanita itu ada tiga, yaitu (1) normatif, (2) substantif, dan (3) prestatif.Normatif ialah peran wanita yang ada dalam lingkungan keluarga yang tidak bias digantikan oleh orang lain, misalnya mendapingi suami, meperhatikan naak, mengurus rumah tangga, mengatur masakan untuk keluarga dan lain sebagainya.

Substantif ialah peran wanita dalam lingkungan tempat tinggal, misalnya dalam pengajian di kampung, pengurus RT/ RW, aktif dalam PKK, 128 | ISSN: 22477-5150 http://journal.unesa.ac.id/index.php/jpi 
dan organisasi lain yang terdapat dalam wiyalah tempat tinggal. Hal ini merupakan kegiatan wanita yang tidak akan mengganggu peran normative dalam keluarga.

Prestatif ialah peran wanita dalam tugas diluar keluarga dan lingkungan, misalnya wanita pekerja di kantor, wanita yang menjabat dalam pemerintahan, wanita yang memiliki karier dalam bisnis dan usaha, wanita yang memiliki tugas dalam kemiliteran, dan sebagainya. Tugastugas yang bersifat prestatif seharusnya tidak dapat menggeser kedudukan wanita sebagai peran wanita normatif.

Nani Sudarsono, mantan Menteri Sosial RI menyatakan bahwa peran ganda perempuan meliputi (1) sebagai ibu rumah tangga, (2) sebagai sumber potensi bangsa, dan (3) sebagai sumber daya manusia (Joehartini, 1996:20). Peran terpenting yang tidak bisa ditinggalkan sebagai perempuan adalah peran pertama, yaitu sebagai ibu rumah tangga dalam keluarga. Peran ini tidak bisa digantikan oleh siapa pun. Oleh Hasniah peran ini dinamakan peran normativ. Sedang peran yang lain merupakan peran tambahan bagi perempuan, seperti peran wanita sebagai sumber potensi bangsa dan peran wanita sebagai sumber daya manusia.

Pendapat Nani Sudarsono (1996) sesuai dengan pendapat Hasniah (1994). Oleh karena itu pendapat Hasniah yang akan digunakan untuk membahas permasalahan dalam penelitian yang berjudul Peran dan Kedudukan perempuandalamCerpen-Cerpen Berbahasa Jawa Abad 21. Utamanya dekade tahun 2000-2010, khususnya gubahan pengarang pria.

Masyarakat Jawa berpandangan bahwa peran dan kedudukan perempuandalam keluargasebagai kanca wingking dan swarga nunut neraka katut.Sepintas menunjukkan bahwaperan perempuan dalam 
keluarga hanyalah sebagai pelengkap. la hanya dianggap sebagai kanca wingking. Bahkankedudukannya sangat bergantung pada kaum pria atau suami. Tetapi bila ungkapan itu dicermati tampak bahwapria sebagai kepala rumah tangga atau tulang punggung keluargamempunyai tanggung jawab yang sangat besar dalam membina rumah tangga. Namun dalam menentukan kebijakan, ketenteraman dan kedamaian dalam keluarga perlu campur tangan seorang ibu sebagai pendamping. Oleh sebab itu dalam menyikapi kedua ungkapan itu harus bijaksana dan memerlukan wawasan yang cukup luas. Dalam kedua ungkapan itu tampak bahwa antara laki-laki dan perempuan dalam keluargamempunyai tugas dan fungsi berbeda, sesuai dengan norma yang berlaku dalam masyarakat. Hal itu dinyatakan dalam pembagian tugas. Dalam hal ini masyarakat Jawa telah membagi secara rapi dan terarah.Berkaitan dengan hal itu, kaum pria tetap harus memegang kendali dalm rumah tangga sebagai kepaladan pelindung keluarga. Kerja sama antarpria dan wanita dalam keluarga menciptakan kedamaian dan ketenteraman.Oleh sebab itu bila keduanya menyadari akan tugas dan kewajiban masing-masing,terjalin kerja sama yang baik, maka ketenteraman keluarga yang didambakan bisa terwujud tanpamemandang rendah satu dengan lainnya, karena yang membedakan pria dan wanita hanyalah kodratnya.

\section{Metode Penelitian}

Koentjaraningrat (1993:16)menyatakan bahwa metode berarti cara kerja untuk memahami suatu objek yang menjadi sasaran ilmu yang bersangkutan. Selanjutnya, mereka menyatakan bahwa suatu metode dipilih dengan mempertimbangkan kesesuaian dengan objek studi, sehingga kecenderungan untuk menempuh jalan yang sebaliknya, yaitu 130 | ISSN: 22477-5150 http://journal.unesa.ac.id/index.php/jpi 
menyesuaikan bahan penelitian atau objek kajian yang bersifat asalasalanseseungguhnya merupakan langkah kerja yang salah.

Penelitianyang berjudul Peran dan kedudukan Wanita dalam Cerpencerpen Berbahasa Jawa Abad 21ini merupakan kajian sastra. Unsur sastra ada dua macam, yaitu unsur intrinsik dan unsur ekstrinsik. Unsur intrinsik meliputi beberapa bagian, seperti tema, alur, sudut pandang, pelaku, karakter, dan sebagainya. Sedangkan unsur. ekstrinsik ialah unsur yangsecara tidak langsung mendukung karya sastra, misalnya sosial, hukum, wanita, religi, agama, kepercayaan, dan sebagainya (Kamidjan, 2004:3). Unsur wanita dalam sastra merupakan unsur ekstrinsik.

Penelitian sastra termasuk jenis penelitian kualitatif (Aminuddin,1990).Umumnya penelitian sastra bersifat deskriptif.Oleh karena itu, penilitian sastra bersifat deskriptif kualitatif.Disain penelitian kualittatif memiliki ciri yang berbeda dengan disain penelitian kuantitatif. Perbedaan itu terletak pada metodologi yang digunakan. Penelitian kualitatif lebih menekankan aspek kebenaran data, teknik pengumpulan data, teknik analisis data, dan pengambilan simpulan penelitian.

Sumber data penelitian ialah cerpen-cerpen berbahasa Jawa tahun 2002 yang termuat dalam majalah Jaya Baya dan majalah Panyebar Semangat yang terbit di Surabaya, Jawa Timur. Hal ini perlu ditegaskan, karena perbedaan lokasi penerbitan akan berdampak pada hasil karya sastra, khususnya cerpen yang memuat tentang peran dan kedudukan wanita. Jumlah cerpen dari kedua majalah tersebur sekitar 104 buah, dengan rincian dari majalah Jaya Baya 52 cerpen dan 52 cerpen lagi dari majalah Panyebar Semangat. Berdasarkan sumber data tersebut peneliti dapat menyeleksi cerpen-cerpen berbahasa Jawa yang di dalamnya 
terdapat unsur peran dan kedudukan wanita.Tidak semua cerpen yang berjumlah 104itu memiliki unsur peran dan kedudukan wanita. Setelah diseleksi, peneliti menemukan 25 cerpen yang memiliki unsur peran dan kedudukan wanita.

Proses pengumpulan data pada penelitian ini menggunakan teknik telaah pustaka, artinya mengkaji teks yang berupa cerita pendek secara teliti untuk mendapatkan data penel.itian.(Supratno,1991:101). Lebih lanjut ia menyatakan bahwa data yang terdapat dalam buku, artikeldiiventarisasi, sebagai data penunjang. Pengumpulan data dilakukan dengan teknik sistem catat, dengan alat bantukartu dan buku catatan. Kartudigunakan untuk mencatat data sesuai dengan masalah yang dikemukakan. Buku catatan berfungsi untuk klasifikasi dan mempermudahanalisis data. Kartu data dibuat sesuai dengan data yang akan dikumpulkan. Umumnya kartu data berwarna merah, hijau, kuning, biru dan sebagainya. Hal ini sesuai dengan klasifikasi data dan permasalahan penelitian.

Langkah-langkah pengunpulan data penelitian dapat dilakukan dengan cara-cara berikut ini(1) Proses pembacaan cerpen-cerpen berbahasa Jawa tahun 2002, pada majalah Jaya Baya dan Penyebar Semangat. (2) Mengkaji cerpen-cerpen tersebut secara struktural dan isi. Hal ini dilakukan untuk mendapatkan data yang diperlukan, karena tidak semua cerpen memiliki unsure peran wanita. Oleh karena itu perlu diseleksi. (3) Mendata peran dan kedudukan wanita dalam cerpen-cerpen yang berbahasa Jawa dalam majalah Jaya Baya dan Panyebar Semangat tahun 2002. (4) Mengelompokkan cerpen-cerpen yang memiliki kesamaan dalam menempatkan para tokoh wanita.

Data yang telah diklasifikasikan siap dianalisis dengan menggunakan 
metode deskripsi dan content analysis. Metode deskripsi analitis (Aminuddin,1990:119) digunakan untuk analisis data yangbersumber dari pustaka, yaitu deskripsi naskah, unsur mitologi, dan unsur sugestidalam naskah Babad Bedhahing Mangir. Surakhmad $(1980 ; 139)$ menjelaskan bahwa penelitian deskriptif adalah menuturkan dan menafsirkan data yang ada sesuai dengan masalah yang diajukan. Dalam hal ini pengkajian sastra lebih tepat bila disebut metode apresiatif, karena peneliti mengapresiasinaskah.Dengan demikian peneliti bertindak sebagai instrumen.

Muhadjir $(1992 ; 76)$ menjelaskan bahwa content analysis(analisis isi) merupakan analisis ilmiah tentang isi atau pesankomunikasi. Secara teknis content analysismencakup upaya (1) klasifikasi, (2) menggunakan kriteria sebagai dasar klasifikasi, (3)menggunakan analisis tertentuuntuk membuat prediksi.Dengan demikian content analysismerupakan suatu teknikyang menekankan makna atau isi yang terdapat dalam objek penelitian. Dalam hal ini ialahcerpen-cerpen yang berbahasa Jawa yang terdapat dalam majalah Jaya Baya dan PanyebarSemangat tahun 2002.

Langkah-langkah yang harus dilakukan dalam analisis data dalam penelitian iniadalah sebagai berikut(1) Mengadakan seleksi data, yaitu menyeleksi terhadap cerpen-cerpen berbahasa Jawa tahun 2002 yang diterbitkan oleh majalah Jaya Baya dan Panyebar Semangat, dengan tujuan untuk memperoleh jumlah dan judul serta nama pengarang yang menggunakan wanita dalam ceritanya. (2) Mengadakan pengumpulan data dengan cara pembacaan cerpen, pencatatan pada kartu data, dan pencatatan pada buku catatan berdasar masalah yang dikemukakan. (3) Mengadakan cek ulang atas data yang telah diperoleh, untuk 
mendapatkan data yang benar-benar akurat. (4) Mengadakan wawancara kepada para pengerang cerpen berbahasa Jawa, terutama pengerang terkenal. (5) Menganalisis data keseluruhan untuk mendapatkan simpulan penelitian.

\section{HASIL PENELITIAN}

Ada sepuluh (10) cerita pendek (cerpen) yang mencerminkan kedudukan wanita sebagai peran normatif, yaitu peran wanita sebagai ibu rumah tangga dalam keluarga. Cerpen-cerpen yang termasuk kelompok ini adalah sebagai berikut(1) Bobote Bubur Lemu karya Ekapti Lenda Aneta (JB, 6/1), (2) Dhuwit Sewu Limangatus karya Hesty IW (JB, 13/1), (3)Titising Panyuwun karya FX Hoery (JB, 17/2), (4) Puguh karya Ismoe Rianto (JB, 24/3, (5) Tumus karya Nono Winarno (JB, 4/4), (6) Anak Nonmer Telu karya Peni kusumawati (JB, 9/6), (7) Sawise Nglairake karya Kurnia WP (JB, 8/9), (i) Setengah Mung Dadi Sangkrah karya Harwimuka (JB, 13/10), (9) Pecut Diseblakna karya Ismoe Rianto (JB, 22/12), dan (10) Sega Liwet Mambu Kringet karya Sudadi (PS, 4/5).

Selain peran normatif di atas, masih ada peran wanita lain yang terdapat dalam cerita pendek (cerpen) berbahasa Jawa tahun 2002 yang dapat dikelompokkan menjadi dua macam, yaitu (1) peran substantif dan (2) peran prestatif. Peran substantif adalah peran wanita di luar rumah, misalnya peran wanita dalam perkumpulan, organisasi, dan dunia usaha. Ada lima (5) cerpen yang memiliki peran wanita substantif yaitu(a) Warung Kopi Pinggir Rel karya Sumono SA (JB, 27/1), (b) Yu Beruk karya Hamdani MW (JB, 2/6), (c) Mitra Lawas karya Duy Monita (JB, 27/6), (d) Kepleset karya Ismoe Rianto (PS, 20/7), (e) Gumantung karya Tiwiek SA (JB, 15/2).Sedangkan peran prestatif adalah peran wanita yang berkaitan 
dengan kedinasan, misalnya peran wanita sebagai guru, polisi, pengacara, dan sebagainya. Berikut disajikan lima (5) cerpen yang memiliki unsur peran wanita prestatif, yaitu(a) Mung Kangen Kawitane karya Harwimuka (JB, 2/6), (b) Sing Eluhe Isih Dleweran karya Ammi EN (JB, 5/5), (c) Brigadir Itong karya Ismoe Rianto (JB, 1/4), (d) Mlungker Maneh karya Putut Wiji (PS, 2/3), (e) Kalung Mutiara karya Maharani Widiyati (PS, 27/4).

Ada delapan (8) kategori cerpen yang mencerminkan peran wanita dalam kehidupan dunia nyata, yaitu(1) Wanita yang berprofesi sebagai guru, (2) wanita yang berprofesi sebagai pengacara, (3) wanita yang berprofesi sebagai polisi negara, (4) wanita yang berprofesi dalam dunia usaha, (5) wanita yang berprfesi sebagai penari tradisional, (6) wanita yang berpegang pada tradisi, (7) wanita yang setia kepada suami, dan (8) wanita yang tidak setia kepada suami. Ada satu (1) cerpen yang termasuk kategori pertama, yaituMung Kangen Kawitane karya Harwimuka (JB, 17/4). Ada satu (1) cerpen yang termasuk kategiri kedua, yaitu Sing Eluhe Isih Dleweran karya Ammi EN (JB, 2/5). Ada satu (1) cerpen yang termasuk kategori ketiga, yaituKalung Mutiara karya Maharani Widiyati (PS, 17/4).Ada lima (5) cerpen yang termasuk kategori keempat, yaitu(a) Yu Beruk karya Ekapti Leda Aneta (JB, 6/1), (b) Warung Kopi Pinggir Rel karya Sumono SA (JB, 27/1), (c) Bobote Bubur Lemu karya Ekapti Lenda Aneta (JB, 6/1), (d) Mitra Lawaskarya Duy Monita (JB, 30/6), (e) Kepleset karya Ismoe Rianto (PS, 20/7). Ada satu (1) cerpen yang termasuk kategori kelima, yaituGumantung karya Ismoe Rianto (JB, 15/12). Ada satu (1) cerpen yang termasuk kategori keenam, yaituSawise Nglairake karya Kurnia WP (JB, 8/9). Ada satu (1) cerpen yang termasuk kategori ketujuh, yaituPecut Diseblakna karya Ismoe Rianto (JB, 22/12). Ada tiga (3) cerpen 
yang termasuk kategori kedelapan, yaitu(a)Titising Panyuwun karya FX Hoery (JB, 17/12), (b) Tumus karya Nono Winarno (JB, 4/4), dan (c) Anak Nomer Telukarya Peni K (JB, 9/6).

Ada tiga (3) kategori penempatan posisi pria dan wanita dalam cerpen berbahasa Jawa tahun 2002, yaitu(1) Dominasi tokoh wanita dalam cerpen, (2) Posisi tokoh wanita sejajar dengan tokoh pria, dan (3) Dominasi tokoh pria.Ada enam (6) cerpen yang termasuk kategori pertama, yaitu(a) Bobote Bubur Lemu karya Ekapti Lenda Aneta (JB, 6/1), (b) Warung Kopi Pinggir Rel karya Sumono SA (JB, 27/1), (c) Sing Eluhe Isih Dleweran karya Ammi EN (JB, 5/5), (d) Yu Beruk karaya Hamdani MW (JB, 12/6), (e) Mitra Lawas karya Duy Monita (JB, 30/6), dan (f) Gumantung karya Tiwiek SA (JB, 15/12). Ada tiga (3) cerpen yang mencerminkan kategori kedua, yaitu(a) Tumus karya Nano Winarno (JB, 14/4), (b) Anak Nomer Telu karya Peni K (JB, 19/6), dan (c) Pecut Diseblakna karya Ismoe Rianto (JB, 22/12). Ada empat (4) cerpen yang termasuk kategori ketiga, yaitu (a) Titising Panyuwun karya FX Hoery (JB, 17/12), (b) Mung Kangen Kawitane karya Harwimuka (JB, 17/4), (c) Lukisan Istimewa karya Daniel Tito (PS, 31/8), dan (d) Puguh karya Ismoe Rianto (JB, 24/3).

Cerpen yang menjadimedia pendidikan untuk meningkatkan kualitas kaum perempuan, Ada lima (5) kategori berdasarkan temuan peneliti, yaitu(1) media pendidikan hidup mandiri, (2) media pendidikan profesi, (3) media pendidikan kesetiaan kepada suami, (4) media pendidikan dunia usaha, dan (5) media pendidikan berkelanjutan. Ada dua cerpen yang termasuk kategori pertama, yaitu(a) Bobote Bubur Lemu karya Ekapti Lenda Aneta (JB, 6/1) dan (b) Puguh karya Ismoe Rianto (JB, 24/3). Ada tiga (3) cerpen yang termasuk kategori kedua, yaitu(a) Mung Kangen Kawitane karya Harwimuka (JB, 7/4), (b) Sing Eluhe Isih Dleweran karya Ammi EN (JB, 136 | ISSN: 22477-5150 http://journal.unesa.ac.id/index.php/jpi 
5/5), dan (c) Kalung Mutiara karya Maharani Widiyati (PS, 27/4). Ada tiga (3) cerpenyang termasuk ke dalam kategori ketiga, yaitu(a) Titising Panyuwun karya FX Hoery (JB, 17/2), (b) Tumus karya Nano Winarno (JB, 14/4), dan (c) Sega Liwet Mambu Kringet karya Sudadi (PS, 4/5). Ada tiga cerpen yang termasuk kategori keempat, yaitu(a) Warung Kopi Pinggir Rel karya Sumono SA (27/1), (b) Mitra Lawas karya Duy Monita (27/6), dan (c) Kepleset karya Ismoe Rianto (PS, 20/7). Ada satu (1) cerpen yang termasuk kategori kelima, yaitu Mlungker Maneh karya Putut Wiji (PS, 12/3).

\section{SIMPULAN}

Berikut disampaikan beberapa butir simpulan penelitian. Adapun simpulan tersebut adalah sebagai berikut: (1) Ada sepuluh (10) cerita pendek (cerpen) yang mencerminkan kedudukan wanita sebagai peran normatif, yaitu peran wanita sebagai ibu rumah tangga dalam keluarga. (2) Selain peran normatif di atas, masih ada peran wanita lain yang terdapat dalam cerita pendek (cerpen) berbahasa Jawa tahun 2002 yang dapat dikelompokkan menjadi dua macam, yaitu peran substantif dan peran prestatif. Peran substantif adalah peran wanita di luar rumah, misalnya peran wanita dalam perkumpulan, organisasi, dan dunia usaha. Ada lima cerpen yang memiliki peran wanita substantif. Selain itu ada lima cerpen yang memiliki peran prestatif. (3) Ada delapan kategori cerpen yang mencerminkan peran wanita dalam kehidupan dunia nyata, yaitu(a) Wanita yang berprofesi sebagai guru, (b) wanita yang berprofesi sebagai pengacara, (c) wanita yang berprofesi sebagai polisi negara, (d) wanita yang berprofesi dalam dunia usaha, (e) wanita yang berprfesi sebagai penari tradisional, (f) wanita yang berpegang pada tradisi, (g) wanita yang 
setia kepada suami, dan (h) wanita yang tidak setia kepada suami. (4) Ada tiga kategori penempatan posisi pria dan wanita dalam cerpen berbahasa Jawa tahun 2002, yaitu(a) Dominasi tokoh wanita dalam cerpen, (b) Posisi tokoh wanita sejajar dengan tokoh pria, dan (c) Dominasi tokoh pria. (5) Cerpen merupakan salah satu media pendidikan untuk meningkatkan kualitas kaum wanita. Ada lima kategori berdasarkan temuan peneliti, yaitu(a) media pendidikan hidup mandiri, (b) media pendidikan profesi, (c) media pendidikan kesetiaan kepada suami, (d) media pendidikan dunia usaha, dan (e) media pendidikan berkelanjutan.

\section{DAFTAR RUJUKAN}

Aminuddin. (editor) 1990. Pengembangan Penelitian Kualitatif dalam Bidang Bahasa dan Sastra. MalangYayasan A3.

Ayatrohaedi. 1990. Citra Wanita dalam Sastra Sunda. Makalah. Disampaikan dalam seminar Sastra Bandingan, Sastra dan wanita di FS UI Depok, 22-23 Desember 1990.

Budiman, Arif. 1982. Pembagian Kerja Secara SeksualSebuah pembahasan Sosiologis tentang Peran Wanita di Dalam Masyarakat. JakartaGramedia.

Darni. 1997. Citra Wanita dalam Novel Jawa Tahun 1980-an. Penelitian Studi Kajian Wanita. JakartaDitbinlitabmas.

Darsono. 1990. Citra Wanita dalam Tiga Novel Sastra Indonesia Pasca 1990. Makalah. Disampaikan dalam seminar Wanita dan sastra di Fs Universitas Kristen Petra Surabaya.

Darusuprapto. 1980. Pennulisan Sastra Sejarah Khusus Babad. Yogyakarta FS-UGM

Dini, NH. 1994. Citra Wanita dalam Sastra sebagai Tokoh Cerita dan 138 | ISSN: 22477-5150 http://journal.unesa.ac.id/index.php/jpi 
sebagai Pekerja dalam Penciptaan Sastra. Makalah. Disampaikan dalam Seminar Wanita dan sastraRelevansi dan Persoalan Wanita Masa Kini di FISIP Unair Surabaya.

Djajanegara, Soenardjati. 1987. Citra Wanita dalam Lima Novel Sinclair Levis. JakartaUI

------. 2000. Kritik Sastra Feminis: Sebuah Pengantar. JakartaGramedia Pustaka Utama.

Ferguson, Mary Anne. 1981. Images of Women in Literature. LondonPalo Alto.

Hasniah. 1994.Tugas Utama Wanita Tetap Dalam Keluarga Al Falah. Edisi 73 TH VII April 1994.

Hendrarsono, Emy Susanti. 1984. Refleksi Gender dalam Karya Sastra Indonesia Modern: Suatu Tinjauan Sosiologis Makalah. Disampaikan dalam seminar Wanita dan sastraRelevansi dan Persoalan Wanita Masa Kini di FISI UNAIR Surabaya.

Hutomo, Suripan Sadi. 1975. Telaah KesusastraanJawa Modern. JakartaPusat Bahasa.

Hutomo, Suripan Sadi. 1988. Kalung BarleanAntologi Puisi Jawa Modern Penyair Wanita. SurabayaPusat Pengabdian Masyarakat IKIP Surabaya.

------. 1990. Kesusasteraan Jawa. SurabayaFPBS IKIP Surabaya Ihroni, TO. 1995. Kajian Wanita dalam Pembangunan. JakartaYayasan Obor Indonesia.

Joehartini. 1996. Pemberdayaan Wanita Menuju Kemandirian Bangsa Jurnal Media Pendidikan dan IImu Pengetahuan, Januari 1996.

Kamidjan. 1996. Pengantar Teori Sastra. SurabayaFPBS-IKIP Surabaya. 
.2003. Pengantar Apresiasi Sastra Indonesia. SurabayaFBS UNESA.

Kuntjaraningrat. 1984. Kebudayaan Jawa. JakartaBalai Pustaka.

-------. 1993. Metode-Metode Penelitian Masyarakat. JakartaGramedia.

Muhajir, Nung. 1992. Metode Penelitian Kualitatif. YogyakartaRake Sarasih.

Moeliono, Anton (editor). 1988. Kamus Besar Bahasa Indonesia. JakartaBalai Pustaka.

Nurgiyantoro, Burhan. 1995. Teori Pengkajian Fiksi. YogyakartaGadjah Mada University Press.

Pancaran Semangat Jaya. 2002. Panyebar Semangat 1-52. SuranayaPT Pancaran Semangat Jaya

Sarwadi. 1974. Pengantar Apresiasi Sastra. YogyakartaFKSS-IKIP Yogyakarta.

Setiyowati, Adi. 1994 Citra Wanita dalam Beberapa Novel Karya YB MangunwijayaMakalah. Disampaikan dalam Seminar Wanita dan SastraRelevansi dan Persoalan Wanita Masa Kini di FISIP UNAIR Surabaya.

Showalter, A. 1988. Modern Literaturary Theory, A Reader. Great BritainChapman and Hall.

Surakhmad, Winarno. 1980. Pengantar Penelitian Ilmiah. Bandung Tarsito.

Sukmono, 1993. Pengantar Sejarah Kebudayaan Indonesia I. YogyakartaKanisius.

Supratno, Haris. 1991. Aspek Sosiologis Cerpen Indonesia. Jurnal Prasasti No. 2 Tahun 1991.

Suwarni. 1991. Peran Wanita dalam Sastra Makalah. Disampaikan dalam Seminar Nasional di IKIP Surabaya.

------. 1996. Emansipasi Wanita dalam Sastra Jawa. Makalah, disampaikan 140 | ISSN: 22477-5150 http://journal.unesa.ac.id/index.php/jpi 
dalam Lustrum UGM X tanggal 18 Oktober 1996 di UGM Yogyakarta.

-------. 1998. Peranan Wanita dalam SastraTanda BhaktiKumpulan Karangan Bahasa, Sastra, dan Budaya Nusantara. YogyakartaFS-UGM. Tarigan, Henri Guntur. 1985. Prinsip-Prinsip Dasar Sastra. BandungAngkasa.

Teew, A. 1984. Sastra dan Ilmu SastraPengantar Teori Sastra. JakartaPustaka Jaya.

Wellek, Rene dan Austin Warren. 1974. Theory of Literature. New York: Colombia University.

Yayasan Djojobojo. 2002. Jaya Baya 1-52. SurabayaYayasan Djojobojo. 